\title{
Heart rate responses to different temperatures in juvenile Poppiana dentata (Randall, 1840)
}

\author{
D. S. Singh ${ }^{a *}$ (D), M. Alkins-Koo ${ }^{a}$, L. V. Rostant ${ }^{a}$ (D) and A. Mohammed ${ }^{a}$

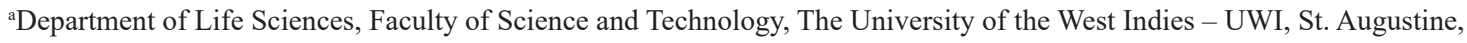 \\ Trinidad and Tobago, West Indies \\ *e-mail: delezia_singh@yahoo.com
}

Received: November 29, 2017 - Accepted: June 19, 2018 - Distributed: February 28, 2020

(With 3 figures)

\begin{abstract}
Temperature is one of the main factors that influences cardiovascular functioning in ectotherms. Hence this study sought to investigate heart rate responses of a freshwater crab species, Poppiana dentata, to different temperature exposures since the species generally reside in habitats of fluctuating physicochemistry. Heart rates were non-invasively determined in juvenile crabs for three temperature regimes, each over an 8-day session; A: temperature exposures of $26{ }^{\circ} \mathrm{C}(2$ days $)$ to $30{ }^{\circ} \mathrm{C}$ ( 3 days) to $26{ }^{\circ} \mathrm{C}$ ( 3 days), B: $26{ }^{\circ} \mathrm{C}$ ( 2 days) to $32{ }^{\circ} \mathrm{C} \mathrm{(3} \mathrm{days)} \mathrm{to} 26{ }^{\circ} \mathrm{C}$ ( 3 days) and $\mathrm{C}$ : a control at constant $26^{\circ} \mathrm{C}$. Heart rate variations were significant among the regimes $(P<0.05)$, with the median heart rate being highest for regime $\mathrm{B}$ ( 74 beats per minute or bpm) during the temperature insult $\left(32^{\circ} \mathrm{C}\right)$, relative to regime $\mathrm{A}(70 \mathrm{bpm})$ and the control (64 bpm). Notably, a suppression and inversion of the diurnal cardiac patterns occurred for regimes' A and B crabs respectively, with rates from the highest temperature insult not shifting back to pre-insult levels during recovery $\left(26^{\circ} \mathrm{C}\right)$. It is plausible that $P$. dentata may have compensatory cardiovascular mechanisms that account for these differential heart rate responses, possibly conveying adaptive strategies in its dynamic habitat conditions.
\end{abstract}

Keywords: heart rate, juvenile crabs, Poppiana dentata, temperature variation.

\section{Respostas de frequência cardíaca do Poppiana dentata jovem a diferentes temperaturas (Randall, 1840)}

\begin{abstract}
Resumo
A temperatura é um dos principais fatores que influenciam o funcionamento cardiovascular dos animais ectotérmicos. Sendo assim, este estudo buscou investigar as respostas de frequência cardíaca de uma espécie de caranguejo de água doce, o Poppiana dentata, após exposição a temperaturas diferentes, visto que esta espécie geralmente reside em habitats de composição físico-química variável. As frequências cardíacas foram determinadas de maneira não invasiva em caranguejos jovens submetidos a três regimes de temperatura, cada um ao longo de uma sessão de oito dias de duração; A: exposição a $26^{\circ} \mathrm{C}$ (dois dias) para $30^{\circ} \mathrm{C}$ (três dias) para $26^{\circ} \mathrm{C}$ (dois dias), B: $26^{\circ} \mathrm{C}$ (dois dias) para $32{ }^{\circ} \mathrm{C}$ (três dias) para $26^{\circ} \mathrm{C}$ (três dias) e C: um controle a temperatura constante de $26^{\circ} \mathrm{C}$. As variações de frequência cardíaca foram significativas entre os regimes $(P<0,05)$, sendo que a frequência cardíaca mediana foi mais alta para o regime $\mathrm{B}$ (74 batimentos por minuto ou bpm) durante o insulto térmico $\left(32^{\circ} \mathrm{C}\right)$, em relação ao regime $\mathrm{A}(70 \mathrm{bpm}) \mathrm{e}$ ao controle (64 bpm). Observou-se particularmente uma supressão e uma inversão dos padrões cardíacos diurnos nos caranguejos dos regimes A e B, respectivamente, sem que as frequências do insulto térmico mais alto voltassem aos níveis anteriores ao insulto térmico durante a recuperação $\left(26^{\circ} \mathrm{C}\right)$. É possível que o $P$. dentata possua mecanismos cardiovasculares compensatórios responsáveis por essas respostas de frequências cardíacas variadas, o que pode indicar estratégias de adaptação às suas condições de habitat dinâmicas.
\end{abstract}

Palavras-chave: frequência cardíaca, caranguejos jovens, Poppiana dentata, variação de temperatura.

\section{Introduction}

Heart rate in crustaceans can be affected by different factors such as temperature, light, salinity and locomotive activity but each of these tends to influence this cardiac aspect in a different way. Most studies examining cardiovascular features have described baseline cardiac patterns in either quiescent (inactive) or active marine crab species (Wilkens et al., 1974; McMahon et al., 1979; Hamilton and Houlihan, 1992; Wachter and McMahon, 1996; De Pirro et al., 1999) whereas others have looked at how cardiac features vary in tandem with a physical, 
physicochemical or biochemical stressor (Ansell, 1973; Florey and Kriebel, 1974; Wilkens et al., 1985; Frederich and Pörtner, 2000). While these studies have extensively examined cardiac responses to stress factors for the marine brachyurans, investigations involving freshwater counterparts have been relatively limited.

Temperature serves as a common stressor in studies exploring cardiac responses in ectotherms since key biological processes such as metabolism, respiration and cardiac activity can be thermally influenced within, and outside, of a particular tolerance range. Bojsen et al (1998) attributed temperature changes as one of the main factors that contributed to $84 \%$ heart rate variation in the freshwater crayfish Astacus astacus. However, Bullock (1955) has reasoned that a species may be sensitive to temperature changes but can still have regulatory mechanisms that can maintain a constant or stable metabolism. The scope of these regulatory adjustments can reflect a particular species response to fluctuations in temperature within its habitat. Cardiac responses to varying temperatures have been examined in some freshwater decapods (Florey and Kriebel, 1974; Villarreal, 1990; Wachter and McMahon, 1996; Wachter and Wilkens, 1996; Bojsen et al., 1998; Goudkamp et al., 2004; Worden et al., 2006) but these responses did not all share a common trend across crustacean taxa. For instance, heart rate and stroke volume in Cancer magister increased and decreased respectively with stepwise temperature changes (Wachter and McMahon, 1996; Wachter and Wilkens, 1996) but a contrasting result was noted for the freshwater crayfish, Cherax tenuimanus, in which heart beats were significantly reduced during increased temperature (Villarreal, 1990).

Variations in both local and global temperatures can consequently generate indirect ecological consequences for freshwater species since observed climate change have already been reported to have impacts on aquatic populations (IPCC, 2014). According to the Fifth Assessment Report on Climate Change by the Intergovernmental Panel on Climate Change (IPCC, 2014), global surface temperatures have increased by $0.85^{\circ} \mathrm{C}$ from the period 1880 to 2012 . On the local scale, riverine sites of Trinidad, similar to those where Poppiana dentata (Randall, 1840) can be found, were reported to have ambient water temperatures ranging from $23.1^{\circ} \mathrm{C}$ to $30.2{ }^{\circ} \mathrm{C}$ (Maharaj and Alkins-Koo, 2007). However, recent physicochemical monitoring of collection sites (for this study) by the authors in 2016 indicated a temperature increase ranging from $26.0{ }^{\circ} \mathrm{C}$ to $30.8{ }^{\circ} \mathrm{C}$. Temperature variations may therefore place pressures on populations of aquatic biota, such as $P$. dentata, that are exposed to fluctuating physicochemical conditions in anthropogenic-modified habitats or seasonally intermittent water bodies. $P$. dentata is a freshwater, lowland species that is mainly an aquatic gill breather with a Neotropical distribution, mainly throughout northern South America (Cumberlidge, 2008). Its extant location in Nicaragua extends its Neotropical range (Cumberlidge, 2008) but this Trichodactylid has also been found in low-lying sites of central and southern rivers of Trinidad (Rostant,
2005); the latter of which have been mainly associated with perturbed water quality (Phillip, 1998).

This study is the first to report on heart rates for a Neotropical crab species under different temperature regimes, with the goal of providing information on cardiac physiological functioning, which may be linked to adaptive mechanisms utilized by $P$. dentata for survival in its dynamic habitats. This species is one of only three freshwater crab species that was reported for Trinidad (Rostant, 2005); with $P$. dentata generally residing in relatively more disturbed habitats of fluctuating physicochemistry, compared to the other two brachyurans. Yet a dearth of information is available for this understudied, indigenous species. Additionally, cardiac functioning in juvenile $P$. dentata is worth exploring since this represents a vulnerable life stage that can be compromised if environmental temperatures reach or exceed an upper tolerance limit for the species. Therefore, this study's focus was to examine the effects of temperature change on heart rates in juvenile crabs by assessing the variation in heart rates and diurnal cardiac patterns from two temperature manipulated regimes of (1) A: $26-30-26{ }^{\circ} \mathrm{C}$ and (2) B: $26-32-26^{\circ} \mathrm{C}$, with comparison to a baseline control of regime $\mathrm{C}$.

\section{Material and Methods}

\subsection{Acquisition of test subjects}

Juvenile $P$. dentata crabs were obtained from berried female wild stock in Bamboo, north-west Trinidad $\left(10^{\circ} 37^{\prime} 49.2^{\prime \prime} \mathrm{N} ; 61^{\circ} 25^{\prime} 51.2\right.$ " W) during the month of June 2016. These crabs were acclimatized in the laboratory for use in this study's experiment. Juvenile crabs in early intermoult phase were selected based on having a carapace width (CW) between 15 to $25 \mathrm{~mm}$, all limbs intact and exhibiting behavioural signs of good health (food acceptance, foraging and locomotion). The lower limit on size was applied at $15 \mathrm{~mm}$ in order to accommodate a proper fit of the heart beat sensor over the cardiac region of the carapace, whereas the upper limit was estimated from Stonley's (1971) account of size ranges for this species.

\subsection{Acclimation}

Juvenile crabs selected for monitoring were kept in separate aquaria (length 8 inches $\times$ width 6 inches $\times$ height 6 inches) to avoid cannibalism and each crab was kept in $1000 \mathrm{~mL}$ of laboratory prepared, de-chlorinated water. Crabs were acclimated for 10 days at an optimum temperature of $26^{\circ} \mathrm{C}$. The extent of the 10 -day acclimation period was deliberately chosen to ensure crabs in late intermoult (nearing a moult event) were not selected for monitoring and the optimum temperature was chosen based on physicochemical monitoring at undisturbed freshwater sites in southern Trinidad (in situ mean: $26.0 \pm 0.3{ }^{\circ} \mathrm{C}$ ), where $P$. dentata crabs can also be found. Preliminary trial experiments with this species also highlighted an ideal ambient temperature of $26^{\circ} \mathrm{C}$ for optimum feeding and growth. Animals were fed $a d$ lib on alternate days with Hikari crab pellets (Kyorin Food Industries Co., Ltd.) 
during acclimation. Water was changed synchronously after each feeding event. Feeding was halted a day before and during the monitoring periods in order to avoid metabolic influences on heart rate responses. During the acclimatization period the weight was measured (Ohaus Scout Pro), along with the carapace length $(\mathrm{CL})$ and width $(\mathrm{CW})$ via a digital (VINCA DCLA) caliper. Dissolved oxygen (DO) at $6.34 \pm 0.16 \mathrm{mg} / \mathrm{L}$ and a $12 \mathrm{~h}$ light ('daytime'): $12 \mathrm{~h}$ dark ('nighttime') photoperiod was maintained throughout both the acclimation and monitoring periods for all regimes.

\subsection{Plan and design}

Non-invasive measurements of heart rates in juvenile $P$. dentata crabs were performed for two temperature manipulated regimes (A, B) and a control regime (C), each over an 8-day monitoring session. Three crabs of the designated size range were assigned to each regime and each cohort was monitored continuously over eight days, categorized into three monitoring periods according to the temperature shifts. The $\mathrm{A}$ and $\mathrm{B}$ regimes consisted of a pre-treatment period of 2 days where crabs were exposed to the optimum temperature of $26^{\circ} \mathrm{C}$, followed by a temperature period of 3 days in which exposure to the respective temperature insult $\left(30^{\circ} \mathrm{C}\right.$ or $\left.32^{\circ} \mathrm{C}\right)$ occurred and then a recovery period of 3 days where subjects were re-introduced to the optimum temperature of $26^{\circ} \mathrm{C}$. The control or regime $\mathrm{C}$ comprised of a constant exposure to the optimum temperature $26^{\circ} \mathrm{C}$, over the same duration as the aforementioned monitoring periods. This control served as a benchmark for baseline heart rates under normal or optimum temperatures.

The pre-treatment duration was purposely reduced to 2 days (instead of 3 ) and the monitoring session for each regime extended to only 8 days in order to ensure that all subjects remained in the intermoult stage. The intermoult period for juvenile $P$. dentata crabs of the selected size range is typically 10 to 11 days (personal observations). The upper temperature selected for regime A was based on similar ambient temperatures $\left(26.0{ }^{\circ} \mathrm{C}\right.$ to $\left.30.8{ }^{\circ} \mathrm{C}\right)$ determined from sites where $P$. dentata were collected. The highest temperature $\left(32^{\circ} \mathrm{C}\right)$ of regime $\mathrm{B}$ was chosen to be above the maximum in situ field reading. Values beyond $32{ }^{\circ} \mathrm{C}$ were not selected for monitoring since these temperatures were known to induce premature moulting in juveniles of this species (based on previous trial experiments by authors).

\subsection{Procedure for monitoring heart rates}

A heartbeat amplifier-logging system designed by Lima and Seabra (2015) was used to non-invasively measure bpm for each hour, of each monitoring period. The concept behind this logger involves emitting and subsequent detection of changes in infrared (IR) light, reflected from within the cardiac chamber enclosing the subject's heart. The IR sensors were attached directly over the cardiac region (posteriorly) on the carapace with non-toxic, coral fixative glue (Seachem Reef Glue ${ }^{\mathrm{TM}}$ ). Crabs were allowed to settle from handling for 1 to 2 hours before commencing heart beat recording. Observations from trial experiments involving the same logger and different crabs substantiated the need for a settling period of this duration. Heart rates in beats per minute (bpm) were continuously recorded by the logger in 1-min sessions for each crab, at 10 minute intervals for every hour of each 8-day session. Each 1-min signal was then individually processed, verified and stored as bpm for each crab ( $\mathrm{N}=1152$ signals/crab), as recommended by the user guidelines (Lima and Seabra, 2015) for quality control confirmation of generated beats. The hourly median and mean heart rates were computed from these individual heart beat values with respect to each crab, $12 \mathrm{~h}$ light: $12 \mathrm{~h}$ dark phases and monitoring period of the respective $192 \mathrm{~h}$ session.

\subsection{Statistical applications}

All data analyses and plots were done using the statistical program $\mathrm{R}$ version 3.2.2 and the alpha level of 0.05 was selected for the rejection benchmark, as this is generally suitable (Dytham, 2011). Normality of the heart rate data (bpm) was explored using the Shapiro Wilk test and descriptive histogram plots while conditions of homoscedasticity/heteroscedasticity for variance were checked using the Levene's Test. Heart rates within each dataset were non-normal in distribution $(P<0.05)$, with unequal variances $(P<0.05)$. Mathematical transformations were applied but the non-normal distribution was retained $(P<0.05)$ so the non-parametric Kruskal-Wallis statistic was used to assess heart rate variation and the Dunn's Test assessed pairwise differences amongst monitoring periods for each regime. Median heart rates according to the light:dark phases, as well as diurnal differences, were also plotted in relation to each regime.

\subsection{Diurnal differences in heart rate}

A d-value for each crab was calculated with respect to each monitoring period (pre-treatment, temperature treatment and recovery) of each regime. This value represented a statistical estimate used to identify diurnal differences for a particular activity, using the formula outlined by Atkinson and Parsons (1973). This latter study incorporated tidal locomotive activity into the formula but this parameter was substituted with diurnal cardiac activity (heart rates) for $12 \mathrm{~h}$ light and dark phases in this study. The d-values for each crab were then plotted and the divergence of these values from 0 was used as a benchmark to examine diurnal differences, and by extension, cardiac patterns in heart rates. Positive and negative d-values denoted greater cardiac activity in the dark ('nighttime') or light ('daytime') phase, respectively. Values that approached 0 denoted little to no diurnal differences between the light and dark phases and those above 1.96 (criteria of $\mathrm{P}<0.05$ ) signified that the d-values were significant. Similar criteria were used for describing tidal rhythmicity in Carcinus maenas crabs (Atkinson and Parsons, 1973) and diurnal heart rate patterns in freshwater crayfish, Astacus astacus (Bojsen et al., 1998). 


\section{Results}

Generally, rates varied considerably across the three monitoring periods within each regime (see Figure 1) (A: $H=89.593$, d.f. $=2, P<0.05 ; \mathrm{B}: H=17.603$, d.f. $=2$, $P<0.05$; C: $H=217.212$, d.f. $=2, P<0.05)$ and amongst the regimes $(H=310.679$, d.f. $=2, P<0.05)$. These dissimilarities were also reflected in the overall median heart rates of $71 \mathrm{bpm}$ (mean: $74 \pm 14 \mathrm{bpm}$ ), $78 \mathrm{bpm}$ (mean: $83 \pm 28 \mathrm{bpm}$ ) and $67 \mathrm{bpm}$ (mean: $70 \pm 16 \mathrm{bpm}$ ) for regimes $\mathrm{A}, \mathrm{B}$ and $\mathrm{C}$, respectively. Heart rates for regime A differed considerably across 192 hours $(H=89.593$, d.f. $=2, P<0.05$ ), with a significant decrease noted from the pre-treatment to the temperature treatment periods (pre-treatment-treatment: $Z=7.780, P<0.05)$. The heart rates of the recovery period were also different from the pre-treatment (pre-treatment-recovery: $Z=8.976, P<0.05$ ). However, elevated heart rates were associated across all 3 periods for regime $\mathrm{B}$, with recordings exceeding $120 \mathrm{bpm}$. As such, the pre-treatment bpm for this regime was similar to those of the treatment $(Z=1.694, P>0.05)$ and recovery periods $(Z=-2.023, P>0.05)$. The 'daytime' and 'nighttime' rates across 192 hours for A and B were both higher than those of $\mathrm{C}$, with the photoperiod rates of $\mathrm{B}$ being the highest and greater than those of the control by $23.9 \%$ and $27.3 \%$, respectively.

\subsection{Heart rate variation and diurnal patterns for pre-treatment period}

Heart rates for the pre-treatment period differed considerably across the three regimes $(H=97.726$, d.f. $=2, P<0.05)$ and these variations were attributable to pairwise differences for $\mathrm{A}-\mathrm{C}(Z=-8.838, P<0.05)$ and $\mathrm{B}-\mathrm{C}(Z=-8.259, P<0.05)$; variations for A-B were not significant $(Z=0.503, P>0.05)$. A median heart rate of $74 \mathrm{bpm}$ was noted for the pre-treatment periods of both $A$ and $B$ regimes (mean A: $76 \pm 12$ bpm; mean $\mathrm{B}: 77 \pm 13 \mathrm{bpm}$ ) along with a diurnal pattern of higher heart rates during the light phase (see Figure 2). This pattern of greater daytime cardiac activity was evident by the majority of the pre-treatment d-values being negative for both A and B (see Figure 3). Pre-treatment rates of these regimes were also higher than that of the control (median C: 68 bpm; mean C: $71 \pm 14$ bpm) along with dissimilar photoperiodic patterns.

\subsection{Heart rate variation and diurnal patterns for treatment period}

Similar to the pre-treatment period, heart rates during the treatment period also differed considerably across the three regimes $(H=310.679$, d.f. $=2, P<0.05)$, with significant variations noted between each regime pair (A-B: $Z=-2.079$, $P<0.05$; A-C: $Z=-14.131, P<0.05$; B-C: $Z=-16.186$, $P<0.05)$. The median bpm for crabs exposed to the temperature insults of regimes' A and B also varied from the control by about 6 to $10 \mathrm{bpm}$ (median A: $70 \mathrm{bpm}$, mean A: $72 \pm 10$ bpm; median B: 74 bpm, mean B: $80 \pm 25$ bpm; median C: $64 \mathrm{bpm}$, mean C: $65 \pm 11 \mathrm{bpm})$. Despite deviation from the control during the temperature insult, the diurnal variation between photoperiods of regime $\mathrm{A}$ was marginal, with a median difference of about $1 \mathrm{bpm}$ between the light and dark phases (see Figure 2). In addition to minimal diurnal variation for this regime, the $d$-values also reflected a suppression in the diurnal cardiac pattern

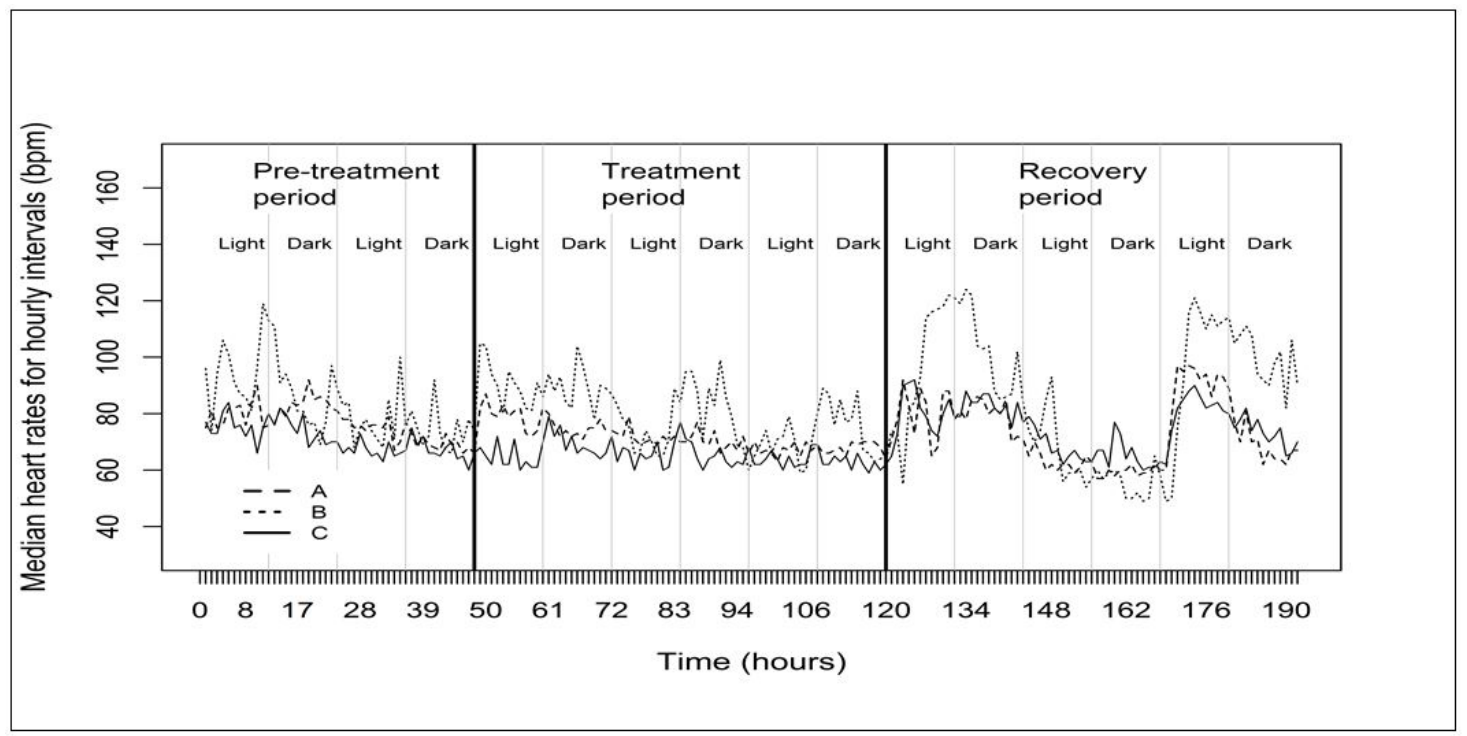

Figure 1. Hourly median heart rates of juvenile $P$. dentata for three regimes (A, B and C), each over a 192h (8-day) session of cardiac monitoring. The vertical solid lines define the three monitoring periods throughout each regime's duration; optimum temperature at $\left(26^{\circ} \mathrm{C}\right)$ (pre-treatment), the temperature insult of $30^{\circ} \mathrm{C}$ for A or $32{ }^{\circ} \mathrm{C}$ for $\mathrm{B}$ (treatment period) and a return to optimum $26^{\circ} \mathrm{C}$ (recovery period). The temperature for regime $\mathrm{C}$ was held constant at $26^{\circ} \mathrm{C}$ throughout the 192 hours since this represented the control. 
since values approached 0 for this monitoring period ( $d=-1.694$ to 1.066 ) (see Figure 3 ). A different cardiac response was noted for crabs of regime B's treatment period since an inversion in the diurnal pattern occurred where elevated heart rates became associated with the dark phase (see Figure 2); the latter was also reflected by the positive d-values of all three replicates for this period (crabs 7, 8 and 9; see Figure 3).

\subsection{Heart rate variation and diurnal patterns for recovery period}

Heart rates also differed across the three regimes $(H=109.672$, d.f. $=2, P<0.05)$ for the recovery period. All pairwise comparison of regimes for this period attributed to these overall differences, with heart rates of crabs recovering from the $30^{\circ} \mathrm{C}$ and $32^{\circ} \mathrm{C}$ exposures being significantly dissimilar (A-B: $Z=-10.060, P<0.05$ ) as well

\section{A}

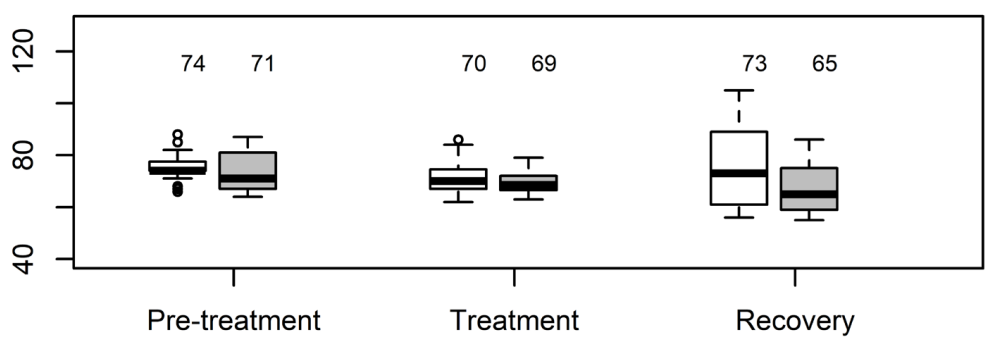

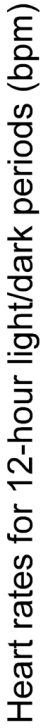

Monitoring periods for regime $\mathrm{A}\left(26-30-26^{\circ} \mathrm{C}\right)$

B

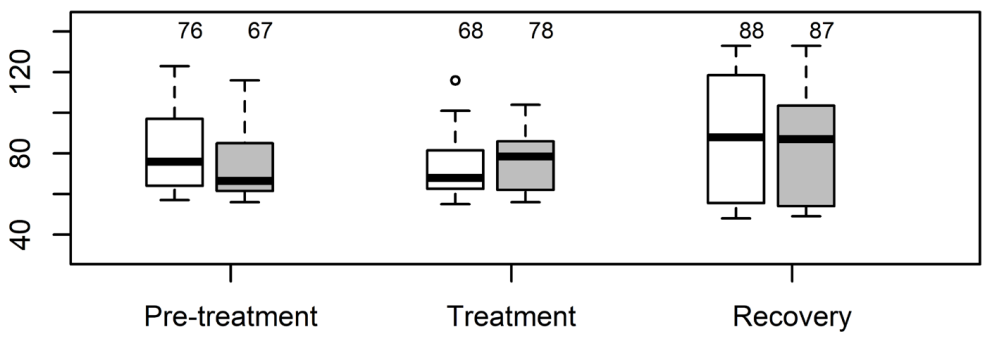

Monitoring periods for regime $\mathrm{B}\left(26-32-26^{\circ} \mathrm{C}\right)$

C

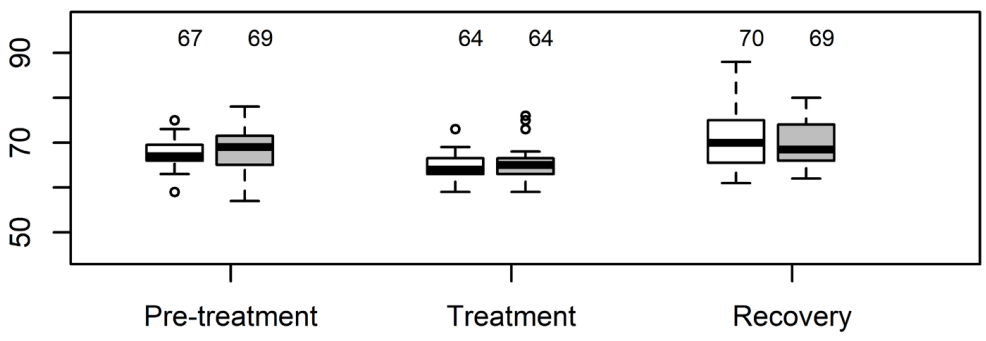

Monitoring periods for the control regime $\mathrm{C}\left(26^{\circ} \mathrm{C}\right)$

bpm under light phase $\square$ bpm under dark phase

Figure 2. Heart rates of juvenile $P$. dentata under different temperature regimes (A, B and C) for $12 \mathrm{~h}$ light: $12 \mathrm{~h}$ dark photoperiod. Boxes represent the interquartile range and the central solid lines represent the respective median heart rates (bpm); these median values are also reported above each respective diurnal phase. The extended hatched lines represent the bpm range for that particular diurnal phase and the open circles represent outliers. 


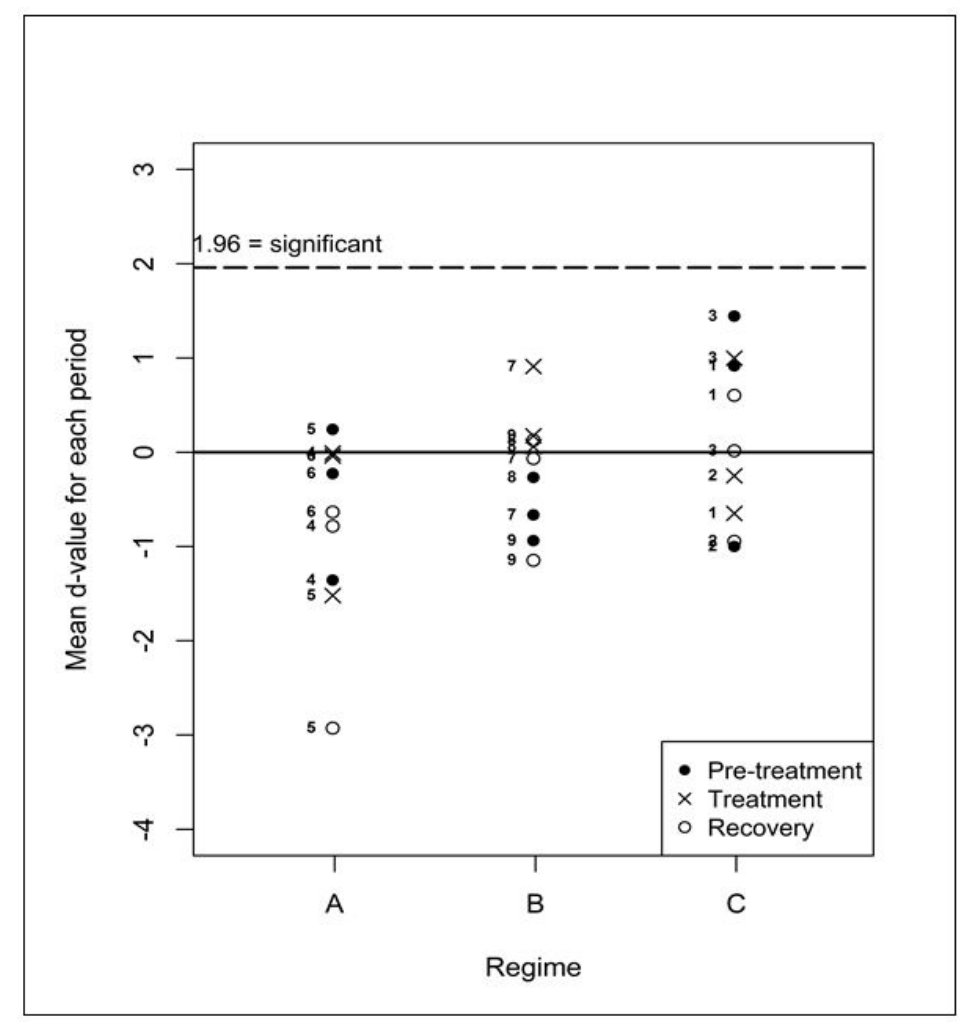

Figure 3. Statistical estimates of diurnal differences in juvenile $P$. dentata heart rates represented by d-values for each monitoring period, within the respective regime. The numbers differentiate the individual crabs assigned to each regime. The solid line demarcates a d-value of 0 which represents minimal or no diurnal differences between light and dark phases. The hatched line demarcates the statistical criterion of 1.96, above which d-values would be considered significant.

as differing from the control (A-C: $Z=2.536, P<0.05$; B-C: $Z=-7.566, P<0.05$ ). Significant bpm elevations were also noted within regimes' $A$ and $B$ recovery sessions (see Figure 1), despite a return to the optimum temperature (A: $H=600.100, d . f .=71, P<0.05$; B: $H=789.100$, d.f. $=71, P<0.05)$. Regime A's crabs maintained the diurnal pattern of higher heart rates during the light phase for the recovery period (see Figure 2). All d-values were negative for crabs during this period (see Figure 3 ). Recovery rates for regime $\mathrm{B}$ however were generally higher than those of regimes' A and C (see Figure 2), exceeding $120 \mathrm{bpm}$ (A median: 68 bpm; A mean: $73 \pm 18$ bpm; B median: 85 bpm; B mean: $87 \pm 31$ bpm; C median: 68 bpm; C mean: $75 \pm 19 \mathrm{bpm}$ ). In addition, crabs of regime $\mathrm{B}$ may have reverted back to their diurnal pre-treatment pattern during recuperation, as evident by 2 of the 3 crabs having negative d-values for this period (crabs' 7 and 9; see Figure 3).

Notably, inter-individual variability in heart rates was observed amongst the juvenile $P$. dentata crabs comprising the control regime (C: $H=195.965, d . f .=2, P<0.05)$. The similarity in photoperiodic median rates that were noted across the monitoring sessions (see Figure 2) was reflected by the d-values that were evenly distributed both above and below 0 (see Figure 3). The inconsistent displacement of $\mathrm{d}$-values indicated that elevated cardiac activity was associated with either the light or the dark phase, depending on the crab associated with the respective $\mathrm{d}$-value. Inter-individual diurnal variations (different d-value displacements from 0 ) were also observed amongst crabs of regime A during pre-treatment, despite exposure to the same optimum temperature as the control $\left(26^{\circ} \mathrm{C}\right)$.

\section{Discussion}

Heart rate variation occurred amongst regimes, along with cardiac diurnal patterns also becoming altered for regime's $\mathrm{A}$ and $\mathrm{B}$ during the temperature changes; this response is not atypical and was expected for brachyurans. A similar response in $C$. magister crabs was observed where heart rates varied in response to changes of an $8{ }^{\circ} \mathrm{C}$ increase (Wachter and McMahon, 1996). Florey and Kriebel (1974) and Zainal et al. (1992) also found that heart rate varied with temperature changes for marine decapods.

\subsection{Heart rate variation and diurnal patterns from pre-treatment to treatment}

Differential heart rate responses were noted for the different temperature insults. Median heart rates for both the light and dark phases of regime A decreased from pre-treatment levels to the treatment period for a temperature change of $4{ }^{\circ} \mathrm{C}$. Regulatory cardiac responses involving 
ganglionic action and redistribution of hemolymph may have been triggered in $P$. dentata in response to the temperature change from optimum to a higher temperature. These would have indirectly enabled a change in heart rates in order to facilitate thermoregulation of internal body temperature during the external thermal change. Cardiac contractions in the form of heart beats, can be enabled by ganglionic action from within the heart wall (Wilkens et al., 1974) in conjunction with thermally sensitive receptors that are also responsible for regulating cardiac activity in crustaceans (Goudkamp et al., 2004). This cardiac action can also be enabled by the thoracic ganglia which have been highlighted as having high sensitivity during stress conditions (Sorenson, 1973). These neural stimulations along with hormonal stimulation from peptides (e.g. proctolin) and monoamines can collectively play an integrated role in regulating cardiac activity (McGaw et al., 1994; Saver et al., 1998; Wilkens, 1999; McMahon, 2001).

Although a decline in heart rates was noted over both light and dark phases during the treatment period, most crabs of regime A appeared to weakly maintain their diurnal pattern throughout the temperature insult. The circadian rhythmicity in cardiac activity was possibly endogenous and still remained internally driven at this temperature $\left(30^{\circ} \mathrm{C}\right)$. Bullock (1955) highlighted that diurnal and tidal rhythms can persist under a range of temperatures so it is likely that this occurred for $P$. dentata when exposed to an upper temperature similar to that of its indigenous habitats.

In relation to regime $\mathrm{A}$, a different response was noted for crabs exposed to the higher temperature insult $\left(32{ }^{\circ} \mathrm{C}\right)$, involving an elevation in heart rates during the 'nighttime' and consequently an inversion of the diurnal pattern. This nocturnal heart rate elevation is congruent with responses of other freshwater decapods to temperature manipulations. Heart rates in quiescent Cherax tenuimanus crayfish increased from 78.0 (Standard Error $=2.1$ ) bpm to 80.1 (Standard Error $=2.0$ ) bpm with a $4{ }^{\circ} \mathrm{C}$ increase (Villarreal, 1990); similar to the dark phase rates of $P$. dentata during the $6{ }^{\circ} \mathrm{C}$ temperature increase (median B: $78 \mathrm{bpm}$, mean B: $80 \pm 25 \mathrm{bpm}$ ). Likewise for another freshwater crayfish, Cherax destructor, heart rates were elevated at $141.61 \pm 7.98$ bpm during heat transfer (Goudkamp et al., 2004); again similar to elevations in regime B where recordings greater than $120 \mathrm{bpm}$ were noted. Interestingly, the alteration in cardiac pattern for the highest temperature insult represented a temporary entrainment or shift in diurnal rhythmicity since the initial, pre-treatment pattern was restored during recovery. Exposure to $32{ }^{\circ} \mathrm{C}$ during the temperature insult may have temporarily altered the heart rate rhythm as part of the circulatory adjustment mechanisms aforementioned, and by extension, caused a change in diurnal patterns.

\subsection{Heart rate variation and diurnal patterns during recovery}

Considerable fluctuations in heart rates were noted for $P$. dentata crabs during the recovery period, following the elevated temperature exposures. This response is also supported by previous baseline experiments involving the same species, where similar fluctuations in heart rates were noted for crabs during the recovery from hypoxia stress (Singh et al., 2017). Furthermore, elevated acetylcholinesterase activity levels were also noted in the ganglia nervous tissue for the recovery session of these experiments; thus supporting the postulation of $P$. dentata performing cardiac regulatory adjustments via ganglionic action, during recuperation. Physicochemical monitoring at the Bamboo settlement sites, where $P$. dentata crabs can be found, indicated temperatures ranging between $27.2^{\circ} \mathrm{C}$ to $30.6^{\circ} \mathrm{C}$ for 2016 (personal observations). High evaporation during the dry season causes the water levels in these aquatic channels to fall and this may result in exposure to higher ambient water temperatures. This freshwater species may likely have adaptive mechanisms, such as cardiac compensatory responses, to deal with adverse or fluctuating environmental temperatures. While it may be plausible that circulatory adjustments may have brought about changes in heart rates for $P$. dentata, it should be noted that the relation between heart rate and circulatory flow is still uncertain in decapods (McGaw et al., 1994; Goudkamp et al., 2004). Further work is still needed on hemolymph distributional patterns and the extent of change this causes in crustacean cardiac activity.

Aside from the complexity of the crustacean cardiovascular system and associated responses, findings at the individual level were also noted. The d-values reflected inter-individual variability in heart rates for juvenile $P$. dentata crabs of the control (regime C) as well as those of regime A during their pre-treatment period. Moreover, crabs in the control regime did not share a common diurnal pattern and this was evident by the extensive spread of d-values on either side of 0 , across the monitoring periods. These cardiac irregularities are not unusual for brachyurans, even amongst conspecifics, since other studies have also identified similar discrete differences in cardiac activity between, and within, crabs of the same species (Aagaard et al., 1995; Aagaard, 1996; Frederich and Pörtner, 2000). Inter-individual responses are therefore key considerations to note when observing crustacean cardiovascular functioning (McGaw et al., 1994). Bennett (1987) also highlighted that individual variability tends to be overlooked in physiological investigations, further emphasizing the importance of monitoring the same test individuals to account for these discrete responses.

The cardiac responses of crustaceans can provide insight into the regulatory mechanisms utilized in aquatic environments of fluctuating temperature. Therefore, this study's findings provide information on heart rate variation in relation to temperature changes and insight into the plasticity of the cardiovascular physiology for this species. This study focused on this life stage but other life history factors such as size, weight and gender may also influence cardiovascular responses to temperature changes. Therefore, extrapolations from this study's findings for the species should be done with consideration of these ecological factors. However, it is still plausible that compensatory mechanisms of the cardiovascular system 
exist in $P$. dentata, conveying adaptive responses to ambient temperature variation within its habitats. This may also have consequences in terms of this species response to contaminants in the aquatic environment; where toxicity of some pollutants, such as pesticides, can become enhanced with increasing temperature.

\section{Acknowledgements}

The authors of this study would like to extend sincere thanks to Fernando Lima and Rui Seabra for their invaluable technical support, as well as Jeniece Germain and Sasenarine Anandisingh for their field assistance. Further gratitude is extended to the farmers of Bamboo Settlement in Trinidad for their support and advice. The authors have declared no financial conflict of interest with regards to the work presented in this study. Furthermore, ethical sanction was granted to the authors by the Campus Ethics Committee (The University of the West Indies St. Augustine, Trinidad and Tobago) for conducting research on this study's species.

\section{References}

AAGAARD, A., 1996. In situ variation in heart rate of the shore crab Carcinus maenas in relation to environmental factors and physiological condition. Marine Biology, vol. 125, no. 4, pp. 765-772. http://dx.doi.org/10.1007/BF00349259.

AAGAARD, A., WARMAN, C.G., DEPLEDGE, M.H. and NAYLOR, E., 1995. Dissociation of heart rate and locomotor activity during the expression of rhythmic behaviour in the shore crab Carcinus maenas. Marine and Freshwater Behaviour and Physiology, vol. 26, no. 1, pp. 1-10. http://dx.doi.org/10.1080/10236249509378924.

ANSELL, A.D., 1973. Changes in oxygen consumption, heart rate and ventilation accompanying starvation in the decapod crustacean Cancer pagurus. Netherlands Journal of Sea Research, vol. 7, pp. 455-475. http://dx.doi.org/10.1016/0077-7579(73)90066-5.

ATKINSON, R. and PARSONS, A., 1973. Seasonal patterns of migration and locomotor rhythmicity in populations of Carcinus. Netherlands Journal of Sea Research, vol. 7, pp. 81-93. http:// dx.doi.org/10.1016/0077-7579(73)90034-3.

BENNETT, A.F., 1987. Interindividual comparisons. In: M.E. FEDER, A.F. BENNETT, W.W. BURGGREN and R.B. HUE, eds. New directions in ecological physiology. Cambridge: Cambridge University Press.

BOJSEN, B.H., WITTHØFFT, H., STYRISHAVE, B. and ANDERSEN, O., 1998. In situ studies on heart rate and locomotor activity in the freshwater crayfish, Astacus astacus (L.) in relation to natural fluctuations in temperature and light intensity. Freshwater Biology, vol. 39, no. 3, pp. 455-465. http:// dx.doi.org/10.1046/j.1365-2427.1998.00297.x.

BULLOCK, T.H., 1955. Compensation for temperature in the metabolism and activity of poikilotherms. Biological Reviews of the Cambridge Philosophical Society, vol. 30, no. 3, pp. 311-342. http://dx.doi.org/10.1111/j.1469-185X.1955.tb01211.x.

CUMBERLIDGE, N., 2008. T134943A4039966, Poppiana dentata. Switzerland: The International Union for Conservation of Nature. http://dx.doi.org/10.2305/IUCN.UK.2008.RLTS. T134943A4039966.en.
DE PIRRO, M., CANNICCI, S. and SANTINI, G., 1999. A multi-factorial experiment on heart rate variations in the intertidal crab Pachygrapsus marmoratus. Marine Biology, vol. 135, no. 2, pp. 341-345. http://dx.doi.org/10.1007/s002270050632.

DYTHAM, C., 2011. Choosing and using statistics: a biologist's guide. Hoboken: John Wiley \& Sons.

FLOREY, E. and KRIEBEL, M.E., 1974. The effects of temperature, anoxia and sensory stimulation on the heart rate of unrestrained crabs. Comparative Biochemistry and Physiology. Part A, Physiology, vol. 48, no. 2, pp. 285-300. http://dx.doi. org/10.1016/0300-9629(74)90709-9. PMid:4151365.

FREDERICH, M. and PÖRTNER, H.O., 2000. Oxygen limitation of thermal tolerance defined by cardiac and ventilatory performance in spider crab, Maja squinado. American Journal of Physiology. Regulatory, Integrative and Comparative Physiology, vol. 279, no. 5, pp. 1531-1538. http://dx.doi.org/10.1152/ ajpregu.2000.279.5.R1531. PMid:11049833.

GOUDKAMP, J.E., SEEBACHER, F., AHERN, M. and FRANKLIN, C.E., 2004. Physiological thermoregulation in a crustacean? Heart rate hysteresis in the freshwater crayfish Cherax destructor. Comparative Biochemistry and Physiology. Part A, Molecular \& Integrative Physiology, vol. 138, no. 3, pp. 399-403. http://dx.doi.org/10.1016/j.cbpb.2004.06.002. PMid:15313496.

HAMILTON, N.M. and HOULIHAN, D.F., 1992. Respiratory and circulatory adjustments during aquatic treadmill exercise in the european shore crab Carcinus maenas. The Journal of Experimental Biology, vol. 162, no. 1, pp. 37-54.

INTERGOVERNMENTAL PANEL ON CLIMATE CHANGE IPCC, 2014 [viewed 29 November 2017]. Climate change 2014: synthesis report contribution of working groups I, II and III to the fifth assessment report of the Intergovernmental Panel on Climate Change [online]. Geneva: IPCC. Available from: http:// www.ipcc.ch/report/ar5/syr/

LIMA, F.P. and SEABRA, R., 2015. 8-Channel heart beat amplifier and logging system version 1.5. Porto: University of Porto. User manual.

MAHARAJ, L.D. and ALKINS-KOO, M., 2007. Use of Benthic Macroinvertebrates to assess anthropogenic impacts in the rivers of Trinidad and Tobago Appendices. St. Augustine: The University of the West Indies. Report to the Environmental Management Authority.

MCGAW, I.J., AIRRIESS, C.N. and MCMAHON, B.R., 1994. Patterns of haemolymph-flow variation in decapod crustaceans. Marine Biology, vol. 121, no. 1, pp. 53-60. http://dx.doi. org/10.1007/BF00349473.

MCMAHON, B.R., 2001. Control of cardiovascular function and its evolution in Crustacea. The Journal of Experimental Biology, vol. 204, no. 5, pp. 923-932. PMid:11171415.

MCMAHON, B.R., MCDONALD, D.G. and WOOD, C.M., 1979. Ventilation, oxygen uptake and haemolymph oxygen transport, following enforced exhausting activity in the dungeness crab Cancer magister. The Journal of Experimental Biology, vol. 80 , no. 1 , pp. 271-285.

PHILLIP, D.A., 1998. Biodiversity of freshwater fishes of Trinidad and Tobago, West Indies. Scotland: The University of St Andrews, 99 p. PhD Dissertation.

RANDALL, J.W., 1840. Catalogue of the Crustacea brought by Thomas Nuttall and JK Townsend, from the West Coast of North America and the Sandwich Islands, with descriptions of such species as are apparently new, among which are included species of different localities, previously existing in the collection 
of the Academy. Journal of the Academy of Natural Sciences of Philadelphia, vol. 8, pp. 106-147.

ROSTANT, W.G., 2005. Freshwater decapod communities of Trinidad and Tobago. St. Augustine: The University of the West Indies, 178 p. M. Phil Thesis.

SAVER, M.A., WILKENS, J.L. and AIRRIESS, C.N., 1998. Proctolin affects the activity of the cardiac ganglion, myocardium, and cardioarterial valves in Carcinus maenas hearts. Journal of Comparative Physiology. B, Biochemical, Systemic, and Environmental Physiology, vol. 168, no. 7, pp. 473-482. http:// dx.doi.org/10.1007/s003600050167.

SINGH, D.S., MOHAMMED, A., ALKINS-KOO, M. and ROSTANT, L.V., 2017. An assessment of cardiac activity and oxygen consumption of a freshwater crab species in Trinidad, Poppiana dentata. St. Augustine: The University of the West Indies.

SORENSON, A., 1973. Demonstration of an action of acetylcholine on the central nervous system of a crab. The Biological Bulletin, vol. 144, no. 1, pp. 180-191. http://dx.doi.org/10.2307/1540155. PMid:4687630.

STONLEY, J.M., 1971. A monograph of the crabs of Trinidad. St. Augustine: The University of the West Indies, 88 p. M.Sc. Thesis.

VILLARREAL, H., 1990. Effect of temperature on oxygen consumption and heart rate of the australian crayfish Cherax tenuimanus (Smith). Comparative Biochemistry and Physiology. Part A, Physiology, vol. 95, no. 1, pp. 189-193. http://dx.doi. org/10.1016/0300-9629(90)90031-M.

WACHTER, B. and MCMAHON, B.R., 1996. Haemolymph flow distribution, cardiac performance and ventilation during moderate walking activity in Cancer magister (Dana) (Decapoda, Crustacea). The Journal of Experimental Biology, vol. 199, no. 3, pp. 627-633. PMid:9318349.
WACHTER, B. and WILKENS, J.L., 1996. Comparison of temperature effects on heart performance of the dungeness Crab, Cancer magister, in vitro and in vivo. The Biological Bulletin, vol. 190, no. 3, pp. 385-395. http://dx.doi.org/10.2307/1543031. PMid:29227701.

WILKENS, J.L., 1999. The control of cardiac rhythmicity and of blood distribution in crustaceans. Comparative Biochemistry and Physiology. Part A, Molecular \& Integrative Physiology, vol. 124 , no. 4 , pp. 531-538. http://dx.doi.org/10.1016/S10956433(99)00146-4.

WILKENS, J.L., MERCIER, A.J. and EVANS, J., 1985. Cardiac and ventilatory responses to stress and to neurohormonal modulators by the shore crab Carcinus maenas. Comparative Biochemistry and Physiology. Part C, Pharmacology, Toxicology \& Endocrinology, vol. 82, no. 2, pp. 337-343. http://dx.doi. org/10.1016/0742-8413(85)90172-0.

WILKENS, J.L., WILKENS, L.A. and MCMAHON, B.R., 1974. Central control of cardiac and scaphognathite pacemakers in the crab, Cancer magister. Journal of Comparative Physiology. A, Neuroethology, Sensory, Neural, and Behavioral Physiology, vol. 90 , no. 1, pp. 89-104.

WORDEN, M.K., CLARK, C.M., CONAWAY, M. and QADRI, S.A., 2006. Temperature dependence of cardiac performance in the lobster Homarus americanus. The Journal of Experimental Biology, vol. 209, no. 6, pp. 1024-1034. http://dx.doi.org/10.1242/ jeb.02082. PMid:16513928.

ZAINAL, K.A.Y., TAYLOR, A.C. and ATKINSON, R.J.A., 1992. The effect of temperature and hypoxia on the respiratory physiology of the squat lobsters, Munida rugosa and Munida sarsi (Anomura, Galatheidae). Comparative Biochemistry and Physiology. Part A, Physiology, vol. 101, no. 3, pp. 557-567. http://dx.doi.org/10.1016/0300-9629(92)90509-O. 